\title{
Economics
}

2021; 10(3): 68-78

$\mathrm{http}: / / \mathrm{www} . \mathrm{sciencepublishinggroup.com} / \mathrm{j} / \mathrm{eco}$

doi: 10.11648/j.eco.20211003.11

ISSN: 2376-659X (Print); ISSN: 2376-6603 (Online)

\section{Public Debt and Economic Growth in Sub-saharan African Countries: A Panel Data Analysis}

\author{
Melkamu Welde Geleta \\ Department of Economics, College of Business and Economics, Wollega University, Nekemte, Ethiopia \\ Email address: \\ melkamuw2@gmail.com \\ To cite this article: \\ Melkamu Welde Geleta. Public Debt and Economic Growth in Sub-saharan African Countries: A Panel Data Analysis. Economics. \\ Vol. 10, No. 3, 2021, pp. 68-78. doi: 10.11648/j.eco.20211003.11
}

Received: May 22, 2021; Accepted: July 10, 2021; Published: July 21, 2021

\begin{abstract}
Most studies made on the effect of public debt on economic growth especially in high or middle-income economies separately or in both argues that debt has positive effect at early stage and then negative after some threshold beyond which it deteriorate economy (Laffer curve effect). In less developed countries like sub Saharan African (SSA) countries public debt is considered as a potential remedy to finance budget deficit. However, its role in economic growth is debatable over a long period. This depends on the way they utilize and inject it in the economy. Thus, this study aimed at investigating the impact of public debt on economic growth (real per-capita GDP) using panel data of 13 years (20052018) in 18 sub-Saharan African countries. The two-step system Generalized Method of Moment (2SSYS-GMM) method is employed and considering the two-way linkage between the two variables simultaneous equation model of two equations is used to identify the effect of public debt on economic growth. The results indicate that a negative and statistically significant bidirectional relationship between public debt and economic growth of the SSA countries considered in the panel. However, it doesn't justify the Laffer curve (non-linear) effect of debt on economic growth. The result also shows that gross national saving, export and broad money has significantly positive effect on economic growth. Thus, the study recommends using debt fund in more productive ways to support the economy. Further, the countries should focus more on national savings mobilization, export promotion and improve money supply management than looking for more debt.
\end{abstract}

Keywords: Public Debt, Economic Growth, System GMM, Simultaneous Equation Model

\section{Introduction}

\subsection{Background of the Study}

Debt especially in developing countries is an important source of financing public budget deficits. Reports of IIF and IMF postulated that following a "moderate rise of $\$ 3.3$ trillion in 2018, the pace of global debt accumulation was much faster at over \$10.8 trillion in 2019". The 255 trilliondollar global debt (public plus private) which accounts $322 \%$ of gross domestic product is recorded the all-time high. Governments have accounted for the lion's share of the rise in global debt since 2007 from less than $\$ 35$ trillion to $\$ 70$ trillion last year [29].

Low and middle-income countries are more susceptible to growing debt from the period of financial crisis (2008) onwards. This is powered by factors including fluctuating commodity prices, quantitative facilitation and low interest rates in high-income countries. With increasing access to international capital markets, many low and middle-income countries shifted away from traditional sources of financing and experienced a sharp rise in external debt [37].

As per WB report, the debt inflows exceeded equity inflows in all regions in 2018 except South Asia where equity inflows accounted for $60 \%$ of total inflows and Europe and Central Asia where debt flows were negative (-\$11 billion). Latin American and the Caribbean region accounted for the largest share of net financial inflows with \$272 billion (27\%), followed by countries in East Asia and Pacific, other than China, $\$ 115$ billion (11\%). China accounted for around $80 \%$ of the combined debt and equity inflows to countries in the region in 2018 [37].

Middle East and North Africa region recorded the fastest 
accumulation in external debt stocks, on average $7 \%$, pushed by the $15 \%$ rise in Egypt, the region's biggest borrower. The rise in external debt stocks outpaced economic growth in many Sub-Saharan African countries over the past decade. The combined ratio of external debt-to-Gross National Income (GNI) averaged 36\% at end of 2018, a marginal change from the prior year, but over 40\% higher than 2009 . Over the period $2009-2018$ the combined GNI of countries in the region rose $51 \%$, measured in U. S. D terms, while the combined external stock increased, on average, by $117 \%$. For some countries the pace of increase in external debt was far more accelerated over this period. For example, external debt stocks rose $423 \%$ in Ethiopia, 38\% in Rwanda and 345\% in Uganda compared to increases of $159 \%, 74 \%$ and $49 \%$ respectively in GNI [37].

Yet, debt is not necessarily important and can be considered as a double edge sword. Sensible utilization of public debt leads to higher economic growth through bridging the financing gaps of the government and improving the capacity of the government to accomplish its social, political and development goals. But, its misuse (financing unprofitable, unrealistic and low efficiency projects) induces negative impact on economic growth in the face of fluctuating exchange rates, declining commodity prices and rising interest rates.

According to the studies of $[19,38]$, on the relationship between public debt and growth using panel data, found a negative effect of the external debt to GDP and external debt as a percentage of GNI ratio on economic growth and a negative interaction between these two debt' measures and investment.

Some literatures are indicating that the impact of debt (measured as total debt to real GDP ratio) depends on some thresholds below which it has positive effect and above which it affects negatively economic growth. The findings of [28], on the title "Debt and Growth Revisited" using data from forty-four countries over about two hundred years with 3,700 annual observations implies that the relationship between government debt and real GDP growth is weak for debt to real GDP ratios below $90 \%$ of GDP, above which the average growth rate of the economy falls. Their findings also indicated for emerging markets however, the threshold for total external debt (public and private) usually denominated in a foreign currency is when total external debt reaches $60 \%$ of GDP, above which the growth rates are roughly cut in half.

Nonetheless, the study on the effect of government debt on economy is limited especially in low-income economies. Thus, this study is aimed at analyzing the effect of public debt on economic growth of 18 SSA countries using panel data over the period 2005 - 2018 to help policy makers prepare appropriate policy measures.

\subsection{Statement of the Problem}

It was found that there is no mutual consensus on the relationship between public debt and economic growth. The relationship can be positive, negative or even non-linear (the thresholds below and beyond which debt has a positive and negative effects respectively on economic growth of a country) subject to a country specific circumstance.

According to the study of [4], public debt can contribute to economic growth enhancement in Malaysia and similar result is forwarded in European countries [12].

On the other hand, the study of [5], on government debt and economic growth of south, central, Latin American and the Caribbean region revealed a negative and robust effect of public debt on economic growth. A time series analysis on the relationship between government external borrowing and economic growth using ARDL model also concluded a negative effect of debt on economic growth in Oman [31].

Cristina Checherita and Philipp Rother [9] investigated the average impact of government debt on per-capita GDP growth in twelve euro countries for over 40 years and found a non-linear impact of debt on growth with a turning point (90 - 100\% of GDP) beyond which debt-GDP ratio has a deleterious impact on growth.

Some researchers have identified as there is no association between debt and growth at low or moderate levels of debt, however there exists a well-defined threshold $(90 \%$, in their estimation) of government debt relative to gross domestic product (GDP) above which economic growth is hindered [27]. These thresholds rests on a simple correlation of high debt levels with slower growth, but no evidence on causality is given.

Consequently, in this paper, the researcher investigated the impact of public debt on Economic growth of SSA countries aiming at whether an increasing and even the higher debt is helping or hindering their economy and conversely, the effect of GDP in attracting debt by applying simultaneous equation with System GMM model focusing on the following research questions.

\subsection{Research Questions}

1) What is the impact of public debt on economic growth of SSA countries?

2) Is there a bidirectional relationship between public debt and economic growth in the SSA countries?

3) Is debt Laffer curve (debt threshold) applicable for SSA countries?

\subsection{Objectives of the Study}

\subsubsection{General Objective}

The main objective of this study is to analyze the impact of public debt on economic growth of SSA countries.

\subsubsection{Specific Objectives}

Specifically, the study will address the following objectives

1) To analyze the impact of public debt on economic growth of SSA countries.

2) To examine if there is a bidirectional relationship between public debt and economic growth of SSA countries.

3) To examine whether debt Laffer curve (debt threshold) is applicable for SSA countries. 


\section{Literature Review}

\subsection{Definition of Terminologies}

Debt refers to money, goods, or services owed by an individual, firm, or government to another individual, firm, or government. Public Debt is also known as government debt, national debt or sovereign debt and is money (credit) owned by central government to creditors within the country (domestic or internal debt) as well as to international creditors. Regardless of what it is called, public debt is the accumulation of annual budget deficits. It is the result of years of government leaders spending more than they take in via tax revenues. A nation's deficit affects its debt and viceversa.

Dictionary of financial terms defined debt as an obligation to repay an amount you owe. According to Cambridge Academic Content Dictionary, debt can be defined as the amount of money that is owed by a person, company, country, etc. and that they usually have to pay interest on.

Debt Financing: is a time-bound activity where the borrower (a company) borrows money to be paid back at a future date with interest at the end of the agreed period (which can be made monthly, half yearly or at the end of the loan tenure). It could be in the form of a secured or collateralized with the assets of the company taking the loan as well as an unsecured loan in which the line of credit is usually less. A firm takes up a loan to either finance a working capital or an acquisition.

\subsection{Trends of Debt Statistics}

World Bank report indicates that, international financial flows (debt and equity combined) to low and middleincome countries is fluctuating over the period 2009-2018 between the lowest record of $\$ 209.4$ billion during 2015 and the highest record of $\$ 1,446.1$ billion during 2013. In 2018 it totaled $\$ 1,032.2$ trillion which was close to $20 \%$ lower than the comparable figure for 2017 which is $\$ 1,274.9$ trillion. Relative to Gross National Income (GNI), aggregate financial flows were equivalent to $3.4 \%$ during 2018, a noticeable decrease from $4.4 \%$ in 2017 , and well short of the $6.9 \%$ recorded in 2010 [37]. This is shown in the following table 1.

Table 1. Aggregate Net Financial Flows to Low and Middle-income Countries, 2009-2018 US\$ (billion).

\begin{tabular}{|c|c|c|c|c|c|c|c|c|c|c|}
\hline & 2009 & 2010 & 2011 & 2012 & 2013 & 2014 & 2015 & 2016 & 2017 & 2018 \\
\hline Net financial flows, debt and equity & 655.6 & $1,373.3$ & $1,323.4$ & $1,212.7$ & $1,446.1$ & $1,117.5$ & 209.4 & 725.5 & $1,274.9$ & $1,032.3$ \\
\hline Percent of GNI (\%) & 4.0 & 6.9 & 5.7 & 4.9 & 5.5 & 4.1 & 0.8 & 2.8 & 4.4 & 3.4 \\
\hline Net Debt Inflows & 170.8 & 719.8 & 715.2 & 580.0 & 804.6 & 525.3 & -318.2 & 210.6 & 734.4 & 528.7 \\
\hline
\end{tabular}

Source: World Bank International Debt Statistics report, 2020

For sovereign borrowers in Sub-Saharan Africa, 2018 was an outstanding year for issuance. Sovereign bond issuance by Sub-Saharan countries continued swiftly in 2018 to reach a new record high of $\$ 17.4$ billion (excluding South Africa) well over double the $\$ 9$ billion issued in 2017. Major oil exporters, Angola and Nigeria, led the way, issuing $\$ 3.5$ billion and $\$ 5.4$ billion, respectively. Cote d'Ivoire, Ghana, Kenya, and Senegal each tapped the markets for around \$2 billion. Proceeds from these issuances were used for infrastructure financing, balance-of-payments support, and refinancing of prior operations. These issuances were a reflection of investor confidence in the region and attractive profits. The 2018 sovereign issues were characterized by longer maturities, and all included a 30-year tranche. Between 2009 and 2018, sovereign borrowers in SubSaharan Africa active in international markets (excluding South Africa) issued around $\$ 46$ billion; countries eligible for IDA resources accounted for 85 percent of those bond issues [37].

\subsection{Theoretical Perspectives}

Based on the assumptions and arguments they rely on, the economic theories developed over time stresses their common and divergent points on the economic effects of public borrowing which may help public policymakers in formulating public debt policies ensuring favorable conditions
There are two competing hypotheses to answer whether debt is one of the competing factors affecting economic growth or not particularly in developing countries. One is the 'debt overhang hypothesis' (theory). This theory is based on the premise that if debt will exceed the country's repayment ability with some probability in the future, expected debt service is likely to be an increasing function of the country's output level. Thus, some of the returns from investing in the domestic economy are effectively 'taxed' away by existing foreign creditors and investment by domestic and new foreign investors is discouraged [7]. As a result, the debtor country shares only partially in any increase in output and exports because a fraction of that increase will be used to service the external debt.

The theory implies that debt reduction will lead to increased investment and repayment capacity and, as a result, the portion of the debt outstanding becomes more likely to be repaid. When this effect is strong, the debtor is said to be on the 'wrong side' side of the debt Laffer curve. The debt Laffer curve refers to the relationship between the amount of debt repayment and the size of debt which shows a limit beyond which debt accumulation depresses growth $[16,10]$.

The other theory is the 'liquidity constraint hypothesis.' The liquidity constraint is captured as a 'crowding out' effect, by which the requirement to service debt reduces funds available for investment and growth. A reduction in the 
current debt service should, therefore, lead to an increase in current investment for any given level of future indebtedness [8]. Other channels through which the need to service a large amount of external obligations can affect economic performance include lack of access to international financial markets and the effects of the stock of debt on the general level of uncertainty in the economy [7].

The scope of debt overhang is much wider in that the effects of debt do not only affect investment in physical capital but any activity that involves incurring costs up-front for the sake of increased output in the future. Such activities include investment in human capital (in terms of education and health) and in technology acquisition whose effects on growth may be even stronger over time.

Growth models analyzing debt to finance consumption goods and capital goods exhibits a negative effect of debt on economic growth. The national debt is a burden for next generations which comes in the form of a declining flow of private income from a lower stock of capital [3, 23].

Meade [20] has identified the diverse channels through which public debt can positively affect economic growth through illustrating the fact that the removal of the "deadweight debt" would raise the incentive of households to save, improve the incentives for work and enterprise, possibly allow for a decrease in income taxation at a later stage as a result of saving interest payments on the budget (improving even more the incentives for work and enterprise).

According to Harrod-Domar growth model (theory), an economic growth of a country is through mobilization of domestic and foreign savings to produce outputs beyond wear out of the means of production of the economy. Therefore, following the balanced growth equation in which saving is equal to investment, external financial sources (debt) stimulates economic growth by satisfying the financial gap between domestic saving and domestic investment.

In the endogenous neo-classical (Solow) growth model with constant returns to capital at the aggregate production level, an increase in the public debt-to-GDP ratio reduces the growth rate by reducing needed capital accumulation (in this model, the private rate of return is lower than the social rate of return because of externalities) which will also be welfare decreasing as there always exists a future generation that will be harmed by such a measure [30].

\subsection{Empirical Literature}

\section{Debt and Economy}

Depending on the realities of different countries and different periods, indebtedness of public authorities can entail both positive and negative effects on various aspects of social and economic life (including on the economic growth rate of the country in question). The size and extent to which they occur depends on several factors some under the direct control (decisions) of the indebted authorities while others with a broader range of actions the manifestation of which may sometimes be hardly predicted.
Findings of different literatures using different types of data and models are different for different countries. Even the use of the same method does not guarantee the same results. For instance, using time series data analysis with ARDL model, [18, 22], found a negative relationship between public debt and economic growth in Sri Lanka and South Africa. [4], by employing the same ARDL method, found a positive effect in the case of Malaysia. One of the reasons might be due to the level of debt a country possesses, together with different stability in macroeconomic conditions.

Some literatures found a non-linear relationship between the ratio of external public debt to GDP and the growth rate in which an external public debt and economic growth are related in an inverted U-shaped curve. This nonlinearity is the result of two opposite (positive and negative) effects on the growth rate of the economy when the proportion of external public debt to GDP increases.

For example, the study of [11], on "a relationship between external public debt and economic growth" using an endogenous growth model with two goods tradable (manufacturing) and non-tradable (non-manufacturing) is presented found the non-linear relationship between debt and economic growth. Domestic technological knowledge is produced only in the tradable sector. The positive effect is therefore, through an increase in production of traded goods which increases the proportion of labor employed in the sector and then resulted in an increasing the growth rate of the economy as the proportion of external public debt to GDP initially increases. This knowledge also overflows into the non-tradable sector.

The negative effect is when the government further issues external debt to finance part of its spending on tradable goods, the country's risk premium increases (equals the world interest rate plus the country's risk premium) and interest payments on total external debt increases when the proportion of external public debt to GDP increases. The country's risk depends positively on the level of external public debt. Households can borrow abroad and have an external credit constraint which results in fall of household's disposable income and then the proportion of savings to GDP declines and resources for capital accumulation decrease, thus the growth rate of the economy decreases [11].

An empirical investigation on the impact of high and growing government debt on economic growth in twelveeuro area countries over a period of about 40 years suggest that the threshold for government debt beyond which it have a negative growth effect is around $70-80 \%$ of GDP [9].

A study made on an Empirical "Analysis of Debt and Growth in Ethiopia" find that debt has a negative as well as non-linear relation with growth [26].

Some studies found the threshold to be even lower than $50 \%$. For instance, with the fear of the governments to impose higher taxes to finance the debt in high performing European economies investors would prefer to channel their 
investments into other developing economies that costs lower to run a business [12]. In advanced economies such as Belgium, Canada, United Kingdom and United states the threshold is in between $21 \%$ and $50 \%$ [17].

According to [35], beyond a certain level (for different types of debt), debt is a drag on growth. For government debt, the threshold is around $85 \%$ of GDP for corporate debt goes beyond $90 \%$ of GDP, and for household debt threshold around $85 \%$ of GDP.

An empirical result of a study in Kenya using time series data over the period 1970 - 1995 indicated that external debt accumulation has a negative impact on economic growth and private investment. However, this study indicates that debt servicing does not appear to affect growth adversely but has some crowding-out effects on private investment [36].

Concerning panel data analysis different researchers have employed various methods as VAR, ARDL, GMM, SYSGMM and etc. Generally, studies that have cross sections and time less than 25 should employ GMM, while studies with more than 25 cross sections and time should use other methodologies.

Besides, very limited research on the relationship between public debt and economic growth have been conducted specifically on the low-income economies, lower-middle income economies and upper-middle-income economies rather they were focusing on the mixed economies and highincome economies. Therefore, this research is aimed at analyzing the impact of public debt on economic growth of SSA countries considering the two-way flow of influence between economic growth (real per capita GDP) and government debt.

\section{Methodology}

\subsection{Data Type and Sources}

The study employed panel data of Eighteen Sub Saharan African countries which is sourced from annual reports and data bases of world development indicators on the websites of World Bank.

\subsection{Model Specification and Methodology}

As we have tried to indicate so far, examining the causal relationship between the public debt and economic growth of SSA counties is the aim of this study. This is by assuming that it is not only debt that affects economic growth but also economic growth by itself can in turn be one of the factors to attract or detract public debt. Because, using public debt for appropriate investment and improving economic growth attracts lenders to send more debt such economies with the expectation of financing it back on time. This implies as economic growth has a power to attract more debt. Hence, undertaking an empirical study focusing on one-way linkage between these variables is not enough and meaningful. In short, there may well be a two-way linkage between GDP and Debt and as a result, it is better to use a simultaneous equation model to investigate their relationship. For simultaneous equations models consisting of two equations, estimates using OLS methods are biased and even inconsistent $[13,14]$.

There are some statistical techniques for a pooled time series, cross- sectional and panel dataset such as two stage least squares (2SLS), weighted two stage least square (W2SLS), three stage least square (3SLS), the generalized method of moments (GMM) and the system generalized method of moments (SYS-GMM) with the help of instrumental variables (IV).

Schmidt [33] pointed out that the 3SLS estimator is only consistent if all disturbance terms and all instrumental variables are uncorrelated, while an unbiased two stage least square (2SLS) or weighted two-stage least square (W2SLS) estimation requires only that the instrumental variables and disturbance terms of each single equation are uncorrelated [15]. In this study, SYS-GMM is selected to test the causal (simultaneous) relationship between economic growth and public debt using panel data of 18 SSA countries.

By being motivated of the simultaneity bias between Real GDP per capita (used as a proxy for economic growth in this study) and public debt, in this paper the researcher will use a two-equation simultaneous equation model with the help of two-step System Generalized Method of Moment with instrumental variable (IV) method. This is because it accounts for endogeneity problems among variables by using the lags of independent variables as an instrumental variable [1] and [2].

The analytical framework that links debt to economic growth (RGDP per-capita) can be analyzed via the basic neoclassical (Solow) growth model derived from the CobbDouglas production function as follows:

$$
Y=A L^{\alpha} K^{1-\alpha}
$$

Where,

$\mathrm{Y}, \mathrm{L}$ and $\mathrm{K}$ are total output, labor force and capital stocks of the economy respectively and $\mathrm{A}$ is technology or efficiency of production. As the variable 'A' captures the total factor productivity effect on growth in output it is assumed that the effect of Debt on GDP also depends on human capital.

Therefore, adapting to our case that Economic growth represented by Real GDP Per capita is determined by many more factors as public debt, Export, Inflation, broad money supply, human development index, and Gross National Savings. The economic growth and debt functions for the simultaneous equation models can be formulated in the following equations (2) and (3) as;

Growth function is:

$$
R g d p=\alpha_{0} D e b t^{\alpha_{1}}+\operatorname{Exp}^{\alpha_{2}}+\operatorname{Inf} f^{\alpha_{3}}+\text { Money }^{\alpha_{4}}+H d i^{\alpha_{5}}+G n s^{\alpha_{6}}+\varepsilon_{i}
$$


And debt function is:

$$
D e b t=\beta_{0} R g d p^{\beta_{1}}+\operatorname{Exp}^{\beta_{2}}+\operatorname{Inf} f^{\beta_{3}}+M o n e y^{\beta_{4}}+H d i^{\beta_{5}}+G n s^{\beta_{6}}+\varphi_{j}
$$

To linearize the relationship between the variables, taking the logarithmic form of both sides of equations 2 and 3 above respectively and the system GMM model can be specified as:

The growth equation is:

$\operatorname{lnRgdp}=\alpha_{0}+\alpha_{1} \operatorname{lnRgdp_{t-1}}+\alpha_{2} \ln D e b t+\alpha_{3} \operatorname{lnDebtsqr}+\alpha_{4} \ln E x p+\alpha_{5} \ln \operatorname{Inf}+\alpha_{6} \operatorname{lnMoney}+\alpha_{7} \ln H d i+\alpha_{8} \operatorname{lnGns}+\varepsilon_{i}(4)$

Where, $\alpha_{i}{ }^{\prime} s$ are vectors of parameters to be estimated (elasticity's of dependent variable (lnRgdp) with respect to the independent variables), $\varepsilon_{i}$ represent the error term.

\subsection{Definition of Variables and Expected Signs for Growth Equation}

$R G d p_{t-1}=$ isone-year lag of economic growth measured by Real Gross Domestic Product Per Capita $(+)$

$\operatorname{lnDebt}=$ logarithm of public (government) debt measure as the percentage of RGDP $(+$ or -$)$

lnDebtsqr $=$ logarithm of squared public (government) debt $(+$ or -$)$

$\ln \operatorname{Exp}=$ logarithm of export as percentage of RGDP $(+)$

$\ln \operatorname{Inf}=\operatorname{logarithm}$ of growth rate of consumer price index (-)

lnMoney $=$ logarithm of groad money supply $(+)$

$\ln H d i=$ logarithm of human Development Index used as a proxy for human capital $(+)$

$\ln G n s=$ logarithm of gross National Saving as a percentage of RGDP (+)

And the public debt equation is:

$$
\left.\ln \text { Debt }=\beta_{0}+\beta_{1} \operatorname{lnDebt}_{t-1}+\beta_{2} \ln R g d p+\beta_{3} \ln \operatorname{Exp}+\beta_{4} \ln \operatorname{Inf}+\beta_{5} \ln M o n e y+\beta_{6} \ln H d i+\beta_{7} \ln G n s+\varphi_{j}\right)
$$

Where, $\beta_{i}{ }^{\prime} s$ coefficients respectively (elasticity's of dependent variable (lnDebt) with respect to the independent variables) and $\Delta$ and $\varphi_{j}$ indicates the first difference of the variables and error term respectively.

\subsection{Definition of Variables and Expected Signs}

$\operatorname{lnDebt}(-1)=$ logarithm of lagged public debt as a percentage of real GDP $(+)$

$\ln R g d p=\operatorname{logarithm}$ of economic growth measured by Real Gross Domestic Product Per Capita (-)

$\ln \operatorname{Exp}=$ logarithm of export as percentage of RGDP $(+)$

$\ln \operatorname{Inf}=\operatorname{logarithm}$ of inflation rate measured by annual growth rate of CPI (-)

lnMoney $=$ logarithm of broad money supply $(+)$

$\ln H d i=$ logarithm of human Development Index used as a proxy for human capital $(+)$

$\ln G n s=$ logarithm of gross National Saving $(+)$

\subsection{Diagnostic Tests}

The simultaneous equation model uses instrumental variables to capture the multicollinearity problem in estimating the two equations. Therefore, the lags of explanatory variables are used as instrumental variables which are also the advantage of using SYM-GMM model. Besides, the tests of serial autocorrelation and over identification problems are checked by Hansen and Sargan tests of AR (1) and AR (2) to confirm the significance of the equations in the model.

\section{Data Analysis and Discussions}

\subsection{Stationarity / Unit Root Test}

Test of stationarity is considered mainly for time series analysis. However, in panel data analysis, it is necessary just to help not to estimate the unrelated variables. Though Augmented Dicky Fuller unit root test is widely used method, the inverse chi-square test of Chi-square distribution with $2 \mathrm{~N}$ degree of freedom is more desirable especially when number of panels is definite [6]. 
In the Table 2 below, the Fisher test of stationarity of the variables with the help of Augmented Dicky Fuller unit-root test by evaluating the null hypothesis: Ho: All panels contain unit roots against the alternative hypothesis: Ha: At least one panel is stationary with the decision rule of rejecting Ho as the probability of the inverse chi-squared of the variable is less than $5 \%$ level of significance confirming that the variable is stationary.

Table 2. Results of Fisher Unit Root Test of Stationarity.

\begin{tabular}{|c|c|c|c|c|c|c|c|c|}
\hline \multirow{2}{*}{ Variables } & \multicolumn{2}{|c|}{ Inverse chi-squared } & \multicolumn{2}{|c|}{ Inverse normal } & \multicolumn{2}{|c|}{ Inverse logit } & \multicolumn{2}{|c|}{ Modified inv. chi-squared } \\
\hline & Statistic & p-value & Statistic & p-value & Statistic & p-value & Statistic & p-value \\
\hline lnrgdppcpt & 109.6057 & 0.0000 & -3.1679 & 0.0008 & -4.7291 & 0.0000 & 8.6745 & 0.0000 \\
\hline Lnhdi & 242.2470 & 0.0000 & -8.4774 & 0.0000 & -14.3605 & 0.0000 & 24.3064 & 0.0000 \\
\hline Lngns & 59.9948 & 0.0073 & -2.1533 & 0.0156 & -2.3334 & 0.0109 & 2.8278 & 0.0023 \\
\hline Lninf & 98.9087 & 0.0000 & -5.5993 & 0.0000 & -5.8816 & 0.0000 & 7.4139 & 0.0000 \\
\hline Lnmoney & 59.3485 & 0.0085 & -2.2840 & 0.0112 & -2.3935 & 0.0093 & 2.7516 & 0.0030 \\
\hline $\ln \exp$ & 82.7470 & 0.0000 & -3.3692 & 0.0004 & -3.7394 & 0.0002 & 5.9114 & 0.0000 \\
\hline lndbtsrvs & 95.9326 & 0.0000 & -4.2445 & 0.0000 & -5.1585 & 0.0000 & 7.0631 & 0.0000 \\
\hline
\end{tabular}

Source: Authors' computation using STATA 15.

\subsection{Descriptive Statistics}

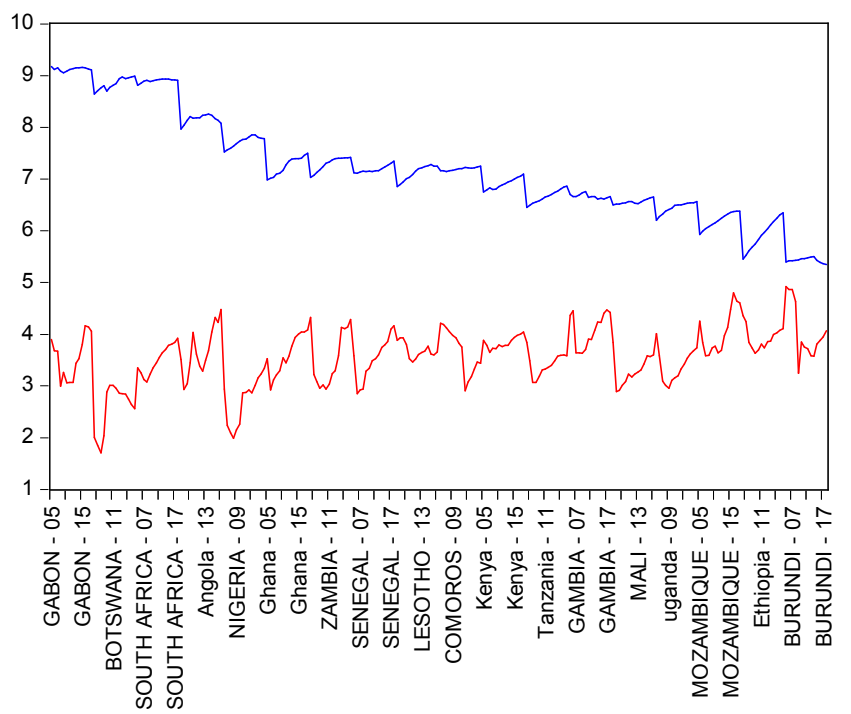

GABON --- BURUNDI (DESSENDING ORDER OF REAL PER CAPITA GDP)

$$
\text { - LNRGDPPCPT — LNDEBT }
$$

Figure 1. The relationship between real GDP per capita and debt.

Source: Author's computation, based on World Bank's World Development Indicators data 2019.

The graph is signifying that the countries with high real per capita GDP have lower debt to its RGDP ratio. However, this does not necessarily mean their stock of public debt decreases with increasing real per capita GDP.

However, there is slightly a positive relationship between the countries real GDP annual growth rate (here represented as GDP) and the countries debt as percentage of real GDP per capita which is shown in the figure below.

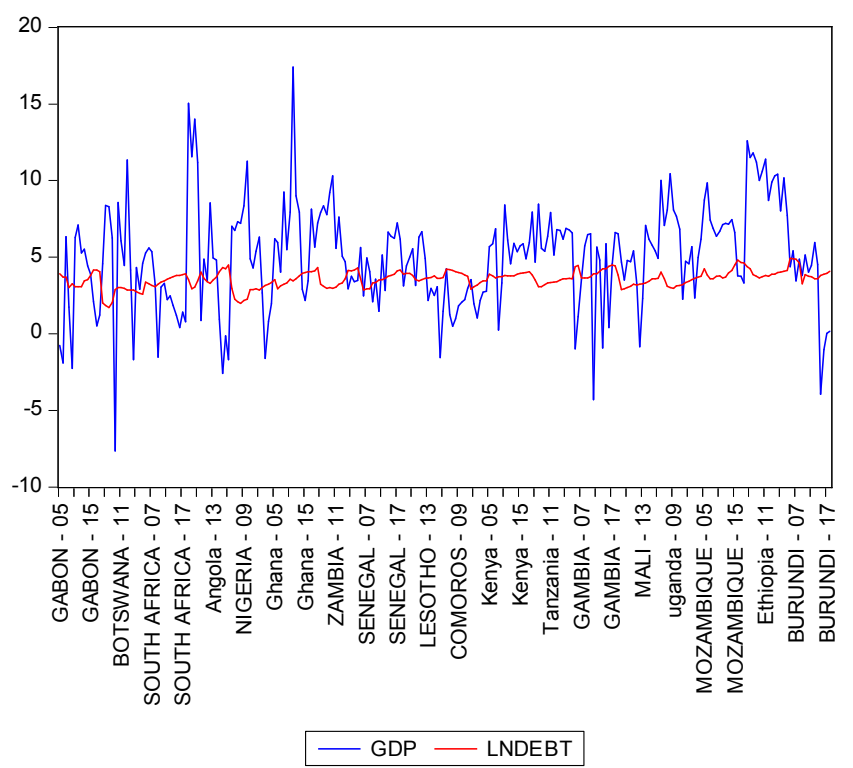

Figure 2. Real GDP growth rate and debt.

\subsection{Econometric Analysis}

Table 3. Granger Causality Tests (Pair wise Granger Causality Tests).

\begin{tabular}{llll}
\hline Sample: $\mathbf{2 0 0 5} 2018$ & & \\
\hline Lags: 2 & & & Prob. \\
\hline Null Hypothesis: & Obs & F-Statistic & 0.2968 \\
\hline Lndebt does not Granger Cause Lnrgdp & 216 & 1.22163 & 0.9759 \\
Lnrgdp does not Granger Cause Lndebt & & 0.02438 & \\
\hline
\end{tabular}

Source: Authors' computation 
From table 3 above, we can conclude that there is a twoway causality between debt and real per capita GDP. This shows as there is a flow of effect from both direction among the variables of interest and justifies the necessity of simultaneous equation model to capture their effects on one another and evaluate which one supports or deteriorates the other. This means the effect of debt on economic growth and vice versa is not only direct but also indirect through influencing one another.

Table 4: Regression Result of GDP Equation

The table below reports the regression result of Dynamic panel-data estimation, two-step system GMM of economic growth equation over the period 2005-2018 for the SSA countries considered in the panel.

Table 4. Regression results of growth equation using Dynamic panel-data estimation, two-step system GMM.

\begin{tabular}{|c|c|c|c|c|c|c|c|}
\hline Lnrgdppcpt & Coef. & St. Err. & t-value & p-value & {$[95 \%$ Conf } & Interval] & Sig \\
\hline L. lnrgdppcpt & .972 & .022 & 43.95 & 0.000 & .929 & 1.015 & $* * *$ \\
\hline Lndebt & -.027 & .005 & -4.94 & 0.000 & -.037 & -.016 & $* * *$ \\
\hline Lndebtsqr & -.411 & .339 & -1.21 & .225 & -1.075 & .253 & \\
\hline Lnexp & .006 & .003 & 2.27 & 0.023 & .001 & .011 & $* *$ \\
\hline Lnmoney & .029 & .011 & 2.53 & 0.011 & .006 & .051 & $* *$ \\
\hline Lnhdi & .026 & .115 & 0.23 & 0.820 & -.199 & .252 & \\
\hline Lngns & .019 & .005 & 3.99 & 0.000 & .009 & .028 & $* * *$ \\
\hline Constant & .187 & .24 & 0.78 & 0.434 & -.282 & .657 & \\
\hline \multicolumn{2}{|c|}{ Mean dependent var } & \multicolumn{2}{|l|}{7.237} & \multicolumn{2}{|c|}{ SD dependent var } & 0.944 & \\
\hline \multicolumn{2}{|c|}{ Number of obs } & \multicolumn{2}{|l|}{137.000} & \multicolumn{2}{|c|}{ Chi-square } & 519980.289 & \\
\hline \multicolumn{2}{|c|}{ Wald chi2 $(7)=519980.29$} & \multicolumn{2}{|c|}{ Prob $>$ chi $2=0.000$} & \multicolumn{2}{|c|}{ Arellano-Bond AR (1) } & 0.096 & \\
\hline \multicolumn{2}{|c|}{ Number of groups } & \multicolumn{2}{|l|}{18} & \multicolumn{2}{|c|}{ Hansen test } & 0.525 & \\
\hline \multicolumn{4}{|c|}{$* * * p<.01, * * p<.05, * p<.1$} & & & & \\
\hline
\end{tabular}

Source: Author's computation using STATA 15, 2019

The table 4 above reports the regression result for economic growth equation.

The inclusion of the lagged dependent variable gives rise to question of serial correlation problem. However, to get consistent estimators, we test the null hypothesis of no serial correlation of the Arellano and Bond AR (1) at first difference. From result above, we accept the null hypothesis at $5 \%$ level of significance justifying the absence of no serial correlation. On the other hand, the probability value of Arellano-Bond test for AR (2) in first differences is also greater than $5 \%$ level of significance indicating no presence of autocorrelation.

Moreover, the Hansen and Sargan test of detecting over identification restrictions which tests the null hypothesis that says instruments as a group are exogenous is also reported. Accordingly, we fail to reject the null hypothesis implying that our model does not suffer from too many instruments. Hence, we are now in a position to infer the regression result which is presented as follows.

As we can see from the table, most of the variables considered in the determination of economic growth have the expected (hypothesized) signs.

As already hypothesized and supported by economic theories, the first lag of real per capita GDP supports the improvement of the future economic growth. That is, the real per capita GDP is positively and significantly influenced by its immediate previous value.

Consistent with what is found in prior panel data studies and as shown in the descriptive analysis, debt has a negative and significant effect on real GDP per capita [19, 34, 38]. That's greater debt accumulation results in weaker economic outcomes in Sub-Saharan African countries (i.e., economies with higher government debt are featured by greater output losses in the SSA countries). This is an indication of the debt overhang problem as suggested by [10]. The result is contrary with the study of [21] which control for the effect of institutional quality in which external debt enhances economic growth.

Export has significantly positive effect on the real per capita GDP of the countries under consideration in the panel. This implies as these developing countries are now a days embarking on export promotion activities through planting different industrial parks and opening it for both domestic and foreign investors.

The broad money supply which is one indicator of macroeconomic performance has a significantly positive effect on the real per capita output of SSA countries. This means the higher money supply leads to higher per capita output (GDP) through its influence on consumption and demand and then production by influencing the price of borrowings to be reduced. The result confirmed the study of $[24,25]$.

Gross national savings has a positive and significant effect on economic growth implying that the higher gross national saving as the percentage of real GDP, the higher the economic growth in the long run which is expected. 
Table 5. Regression result of Debt Equation using Dynamic panel-data estimation, two-step system GMM.

\begin{tabular}{|c|c|c|c|c|c|c|c|}
\hline Indebt & Coef. & St. Err. & t-value & p-value & {$[95 \%$ Conf } & Interval] & Sig \\
\hline L. Indebt & .78 & .117 & 6.70 & 0 & .552 & 1.009 & $* * *$ \\
\hline lnrgdppcpt & -.288 & .102 & -2.83 & .005 & -.488 & -.088 & $* * *$ \\
\hline $\ln \exp$ & -.005 & .022 & -0.21 & .836 & -.048 & .039 & \\
\hline $\operatorname{lninf}$ & -.19 & .06 & -3.18 & .001 & -.307 & -.073 & $* * *$ \\
\hline Inmoney & .169 & .051 & 3.30 & .001 & .069 & .269 & $* * *$ \\
\hline Inhdi & 1.135 & .511 & 2.22 & .026 & .133 & 2.136 & $* *$ \\
\hline lngns & -.036 & .036 & -1.00 & .318 & -.107 & .035 & \\
\hline Constant & 3.485 & 1.492 & 2.33 & .02 & .56 & 6.41 & $* *$ \\
\hline \multicolumn{2}{|c|}{ Mean dependent var } & \multicolumn{2}{|l|}{3.524} & \multicolumn{2}{|c|}{ SD dependent var } & 0.519 & \\
\hline \multicolumn{2}{|c|}{ Number of obs } & \multicolumn{2}{|l|}{137.000} & \multicolumn{2}{|c|}{ Chi-square } & 1249.109 & \\
\hline \multicolumn{2}{|c|}{ Wald chi2 $(7)=1249.11$} & \multicolumn{2}{|c|}{ Prob $>$ chi $2=0.000$} & \multicolumn{2}{|c|}{ Arellano-Bond AR (1) } & 0.157 & \\
\hline \multicolumn{2}{|c|}{ Number of instruments } & \multicolumn{2}{|c|}{17} & \multicolumn{2}{|c|}{ Arellano-Bond AR (2) } & 0.536 & \\
\hline \multicolumn{2}{|c|}{$\begin{array}{l}\text { Number of groups } \\
* * * p<.01, * * p<.05, * p<.1\end{array}$} & \multicolumn{2}{|l|}{18} & \multicolumn{2}{|c|}{ Hansen test } & 0.659 & \\
\hline
\end{tabular}

Source: Author's computation using STATA 15, 2019

The estimated result of the System GMM for debt equation is illustrated in table 5. The regression result reveals that, one-year lag of debt has positively significant effect on attracting more debt. That is countries experiencing borrowing has a likelihood of attracting more debt in the future.

However, the real per capita GDP has significantly negative effect. That is the countries likelihood of attracting higher debt is inversely related with per capita real GDP. This result chains the descriptive analysis shown by figure 1 above.

The result also is indicating that the countries investing more on their human capital development which is proxy by Human Development Index (HDI) in this study are attracting more public debt in the SSA countries. It is an implication of the debt amount increases with improving labour productivity.

Further, as postulated both Gross National Saving and inflation has significantly negative effect on debt attraction. Since higher national savings improves the capacity of their economy to feed itself, it discourages the borrowings. This implies, the more the county's national savings the less she demands for more debt (less dependency on debt). But, the negative and significant effect of inflation is a confirmation of discouraging effect of macroeconomic instability on public debts. In other words, inflation discourages investments which in turn discourage lenders to provide more debt for the countries with high inflation which confirms the result of study by [32].

On the other hand, debt service has positively significant effect on debt as hypothesized. Thus, the debt servicing capacity of the countries is positively affecting debt attracting ability of these SSA countries considered in the panel.

\section{Conclusions and Recommendations}

\subsection{Conclusions}

The objective the research is to analyze the effect of public debt on economic growth of 18 SSA countries using the panel data of 13 years (2005-2018). The system GMM dynamic panel data model is employed focusing on the simultaneous (two way) relationship between the economic growth (real per capita GDP in this study) and debt (debt as a percentage of RGDP in this study) to capture the effects running from both sides. Furthermore, the Hasnsen and Sarjan Overidentification tests are confirmed the appropriateness of the model.

The regression result of economic growth equation is indicating that debt has a significantly negative (debt overhang) effect on economic growth in SSA countries under consideration. However, export, broad money and gross national savings all as a percentage of real GDP has positive and significant effect on economic growth of these SSA countries considered in the analysis. But, human development index and debt square variables have insignificantly positive and negative effects on economic growth of the countries.

Similarly, the counter equation of economic growth, debt equation regression result is showing as one-year lag of debt, human development index and debt service has significantly positive effect to attract more debt in these countries. However, gross national savings and inflation has significantly negative effect on debt while export capacity of these SSA countries is insignificantly affecting their debt attracting capacity.

\subsection{Recommendations}

1) Since the higher debt deteriorates economic growth and is compromising the welfare of the future generation, their economic policies should favor lowering public debt and improving domestic savings in SSA countries.

2) The government of these countries should focus on export promotion and import substitution strategies.

3) The macro-economies of the countries should get more attention in order to stabilize it.

4) Debt should be directed towards productive investment sectors like human capital development (education, health care ant ect) to improve the productivities of their nations.

5) Since it is an indication of using debt in a way of promoting economy, creating greater income and 
market potential, economic growth of these countries should get close attention to attract and be benefited from it and minimize the debt overhang problem.

\section{Acknowledgements}

First and for most praise to Almighty GOD for all. Also, I like to express my profound gratitude and appreciation to Firdisa Biru (Assi. Prof of Economics) and Tesfaye Fikadu (PhD candidate) both at Wollega University for their helpful comments during the work of the paper.

\section{References}

[1] Arellano, M., and S. Bond. (1991). Some tests of specification for panel data: Monte Carlo evidence and an application to employment equations. Review of Economic Studies 58: 277-297.

[2] Blundell, R., and S. Bond. (1998). Initial conditions and moment restrictions in dynamic panel data models. Journal of Econometrics 87: 115-143.

[3] Buchanan, J. M. (1958), Public Principles of the Public Debt, Homewood, Illinois.

[4] Burhanudin, M. D. A., Muda, R., Nathan, S. B. S., \& Arshad, R. (2017). Real effects of government debt on sustainable economic growth in Malaysia. Journal of International Studies, 10 (3), 161-172. doi: 10.14254/2071-8330.2017/10$3 / 12$.

[5] César Calderón and J. Rodrigo Fuentes 2013. Government Debt and Economic Growth: Inter-American Development Bank Fiscal and Municipal Management Division. IDB WORKING PAPER SERIES No. IDB-WP-424.

[6] Choi, In. (2001). Unit Root Tests for Panel Data. Journal of International Money and Finance. 20. 249-272. 10.1016/S0261-5606(00)00048-6.

[7] Claessens, S., E. Detragiache, R. Kanbur, and P. Wickham (1996). 'Analytical Aspects of the Debt Problems of Heavily Indebted Poor Countries'. Paper presented to IMF/World Bank seminar in December. Washington, DC: World Bank.

[8] Cohen, D. (1993), "Low Investment and Large LDC Debt in the 1980s," American Economic Review, Vol. 83 (3), pp. 437-49.

[9] Cristina Checherita And Philipp Rother 2010. The Impact of High and Growing Government Debt on Economic Growth: An Empirical Investigation for The Euro Area. Working Paper Series, No 1237 / August 2010.

[10] Elbadawi, I. A., Ndulu, B. J., Ndung'u, N. (1997), Debt overhang and economic growth in Sub-Saharan Africa. In: Iqbal, Z., Kanbur, R., editors. External Finance for Low-income Countries. Washington, DC: International Monetary Fund.

[11] Enrique R. Casares (2015). 'A relationship between external public debt and economic growth' Universidad Aut'onoma Metropolitana-Azcapotzalco: Estudios Econ'omicos, vol. 30, n'um. 2, julio-diciembre 2015, p'aginas 219-243.

[12] Gómez-Puig, M., \& Sosvilla-Rivero, S. (2017). Heterogeneity in the debt-growth nexus: Evidence from EMU countries.
International Review of Economics and Finance, 51, 470-486. doi: 10.1016/j.iref.2017.07.008.

[13] Greene WH (2003). Econometric Analysis. Prentice Hall, 5th edition.

[14] Gujarati, D. N. (2003) Basic Econometrics. 4th Edition, McGraw-Hill, New York.

[15] Henningsen, Arne \& Hamann, Jeff. (2007). systemfit: A Package for Estimating Systems of Simultaneous Equations in R. Journal of Statistical Software. 23. 10.18637/jss.v023.i04.

[16] Krugman, Paul (1988). "Market-Based debt Reduction Schemes," NBER working Paper, 2587, Cambridge.

[17] Lee, S., Park, H., Seo, M. H., \& Shin, Y. (2017). Testing for a debt-threshold effect on output growth. Fiscal Studies, 38 (4), 701-717. doi: 10.1111/1475-5890.12134.

[18] Maitra, B. (2019). Macroeconomic impact of public debt and Foreign Aid in Sri Lanka. Journal of Policy Modeling, 41 (2), 372-394. doi: 10.1016/j.jpolmod.2019.03.002.

[19] Markus Eberhardt and Andrea F. Presbitero 2015. Public debt and growth: Heterogeneity and non-linearity. Journal of International Economics. journal homepage: www.elsevier.com/ locate/j i e. INEC-02861; No of Pages 14.

[20] Meade, J. E. (1958), “Is the National Debt a Burden?" Oxford Economic Papers, New Series, Vol. 10 (2), pp. 163-183.

[21] Mensah, Lord \& Bokpin, Godfred \& Boachie Yiadom, Eric. (2018), External Debts, Institutions and Growth in SSA. Journal of African Business. $19.1-16$. 10.1080/15228916.2018.1452466.

[22] Mhlab, N., \& Phiri, A. (2019). Is public debt harmful towards economic growth? New evidence from South Africa. Cogent Economics and Finance, 7 (1). doi: $10.1080 / 23322039.2019 .1603653$.

[23] Modigliani, F. (1961), "Long-Run Implications of Alternative Fiscal Policies and the Burden of the National Debt", Economic Journal, 71 (284), pp. 730-755.

[24] N. M. Gatawa, Akinola Abdulgafar, Muftau O. Olarinde (2017). 'Impact of Money Supply and Inflation on Economic Growth in Nigeria' (1973-2013): IOSR Journal of Economics and Finance (IOSR-JEF) e-ISSN: 2321-5933, p-ISSN: 23215925. Volume 8, Issue 3 Ver. IV (May - June 2017), PP 26-37.

[25] Omodero, Cordelia. (2019). Effect of Money Supply on Economic Growth: A Comparative Study of Nigeria and Ghana. International Journal of Social Science Studies. 7. 16. 10.11114/ijsss.v7i3.4137.

[26] Ramakrishna G. (2002) External Debt of Ethiopia: An Empirical Analysis of Debt and Growth. Journal of Business and Public Affairs.

[27] Reinhart, C. M. and K. S. Rogoff (2009), "The Aftermath of Financial Crisis", American Economic Review, Vol. 99 (2), pp. $466-472$.

[28] Reinhart, C. M., Reinhart, V., \& Rogoff, K. (2015). Dealing with debt. Journal of International Economics, 96 (S1), S 4355. doi: 10.1016/j.jinteco.2014.11.001.

[29] Robin K. and Simon P. (2019), IMF Working Papers. "Capital Flow Data - A Guide for Empirical Analysis and Real-Time Tracking". 
[30] Saint-Paul, G. (1992), "Fiscal policy in an Endogenous Growth Model", Quarterly Journal of Economics, No. 107, pp. 1243-1259.

[31] Sami Al Kharusi and Mbah Stella Ada 2015. External Debt and Economic Growth: The Case of Emerging Economy. Journal of Economic Integration. Vol. 33 No. 1, March 2018, 1141 1157 http://dx.doi.org/10.11130/jei.2018.33.1.1141.

[32] Samia O. B. and Hanen O., 2017. Macroeconomic determinants of public debt growth: A case study for Tunisia, Theoretical and Applied Economics. Volume XXIV (2017), No. 4 (613), Winter, pp. 161-168.

[33] Schmidt P. (1990). "Three-Stage Least Squares with Different Instruments for Different Equations." Journal of Econometrics, 43, 389-394.

[34] Senadza, Bernardin; Fiagbe, Agbemavor Korsi; Quartey, Peter (2018): The effect of external debt on economic growth in
Sub-Saharan Africa, International Journal of Business and Economic Sciences Applied Research (IJBESAR), ISSN 2408-0101, Eastern Macedonia and Thrace Institute of Technology, Kavala, Vol. 11, Iss. 1, pp. 61-69.

[35] Stephen G. Cecchetti, M S Mohanty and Zampolli F. (2011). 'The real effects of debt': BIS Working papers No 352.

[36] Were, M. (2001). The Impact of External Debt on Economic Growth in Kenya: An Empirical Analysis, Discussion Paper, 116, WIDER, October.

[37] World Bank. International Debt Statistics 2019. Washington, DC: World Bank. doi: 10.1596/978-1-4648-1461-7. License: Creative Commons Attribution CC BY 3.0 IGO.

[38] Zouhaier H. \& Fatma M. (2018). 'Debt and Economic Growth' International Journal of Economics and Financial Issues' Vol. 4, No. 2, 2014, pp. 440-448; ISSN: 2146-4138: www.econjournals.com. 